\title{
PENGARUH AKULTURASI DALAM PROSES INTERAKSI ANTARBUDAYA TERHADAP KESADARAN BUDAYA BERBAHASA DAERAH SETEMPAT BAGI MAHASISWA RANTAU
}

\author{
A. Dian Fitriana \\ Institut Agama Islam Negeri (IAIN) Parepare \\ Email: adianfitriana@stainparepare.ac.id
}

\begin{abstract}
a communication process or intercultural interaction, an immigrant conducts some activities as a self- adaptation to the local culture called acculturation. The adaptation is supported by the cultural awareness of local language that becomes the supporting factor. The research was aimed at finding out how big the influence of acculturation consisting of personal communication, social communication, communication environment, and acculturation potential toward the awareness of language culture involving knowledge, attitude, and behavior. The research used the quantitative method with the Path Analysis approach. The sampling technique used was Disproportional Stratified sampling. The data were obtained through questionnaires, interview, observation, and documentary study. The result of the research shows that there was significant influence of personal and social communication in the intercultural interaction process toward the cultural awareness of local language among the South Sulawesi students in Bandung, shown by the percentage of each factor which was: $36.8 \%$ and $48.6 \%$. The research also showed that there was no significant influence of communication environment and acculturation potential in the intercultural interaction process toward the cultural awareness of local language among the South Sulawesi students in Bandung shown by the percentage of 13.3 $\%$ and $1.3 \%$.
\end{abstract}

Keywords: Intercultural Communication, Acculturation, Awareness of language culture

\section{PENDAHULUAN}

Dewasa ini sangat sering ditemukan banyaknya masyarakat yang melakukan migrasi atau perpindahan penduduk dari tempat satu ke tempat lainnya, baik itu ke luar negeri maupun hanya di dalam negeri khususnya di Indonesia. Hal tersebut memicu suatu interaksi yang terjadi antara para pendatang dengan masyarakat setempat, dimana keduanya memiliki latar belakang budaya yang berbeda. Hal tersebut pun terjadi pada para perantau yang berasal dari Sulawesi Selatan yang berada di Kota Bandung. Sehingga diperlukan suatu pola 
penyesuaian diri dengan para masyarakat setempat di Kota Bandung (masyarakat Sunda). Proses yang dilakukan oleh mahasiswa pendatang untuk menyesuaikan diri dengan dan memperoleh budaya pribumi, merupakan proses Akulturasi.

Salah satu alat komunikasi adalah bahasa. Bahasa memiliki peranan yang sangat penting dalam membangun suatu pola akulturasi. Hal tersebut dapat mendekatkan jarak sosial, ekonomi-budaya diantara anggota-anggota masyarakat. Dalam membentuk suatu masyarakat multibudaya yang unggul, diperlukan suatu kesadaran budaya baik itu kebudayaannya sendiri maupun kebudayaan suku lain yang menjadi tempat. Untuk menjadi masyarakat antarbudaya diperlukan suatu kesadaran dari diri setiap individu dalam berbudaya salah satunya adalah budaya berbahasa. Sehingga dengan adanya penelitian ini diharapkan para mahasiswa pendatang dapat mengetahui pentingnya penerapan akulturasi untuk membangun suatu kesadaran budaya di dalam diri setiap individu masyarakat perantau atau pendatang, khususnya para mahasiswa Sulawesi Selatan di Kota Bandung.

\section{Perumusan Masalah}

Berdasarkan latar belakang situasi yang telah diuraikan, maka dirumuskan permasalahan dalam penelitian ini sebagai berikut. "Seberapa besar pengaruh Akulturasi dalam proses interaksi antarbudaya terhadap kesadaran budaya berbahasa dikalangan mahasiswa Sulawesi Selatan di Kota Bandung?". Pada dasarnya, perumusan masalah ini merupakan wujud dari interaksi antarbudaya dalam bentuk sederhana di lingkungan yang akan diteliti, yakni mahasiswa Sulawesi Selatan di Wilayah Utara Kota Bandung. Selanjutnya, pertanyaan besar dalam rumusan permasalahan ini diuraikan dalam pokok-pokok sbb.

1. Seberapa besar pengaruh Akulturasi yang meliputi Komunikasi Persona, komunikasi sosial, lingkungan komunikasi dan potensi akulturasi dalam proses interaksi antarbudaya terhadap kesadaran budaya berbahasa di kalangan mahasiswa Sulsel di Kota Bandung?

2. Berapa besar Pengaruh lain (Epsilon) terhadap kesadaran budaya berbahasa? 
Dian Fitriana, Pengaruh Akultrasi dalam Proses...

\section{Kajian Pustaka}

Manusia tidak bisa menghindar dari kehidupan sosialnya. Kehidupan sosial tersebut ditunjang oleh komunikasi sehingga disebutkan bahwa komunikasi merupakan hal yang sangat penting. Manusia dapat mengekspresikan dirinya, membentuk jaringan sosial dan mengembangkan kepribadiannya dalam berkomunikasi. Porter dan Samovar mengemukakan bahwa ; "hampir setiap orang membutuhkan hubungan sosial dalam berinteraksi dengan orang-orang lainnya" (dalam Mulyana dan Rakhmat, 2009). Kebutuhan ini terpenuhi melalui pertukaran pesan yang berfungsi sebagai jembatan untuk mempersatukan manusia-manusia.

Budaya menampakkan diri dalam pola bahasa dan bentuk-bentuk kegiatan dan perilaku yang berfungsi sebagai model-model bagi tindakan penyesuaian diri dan gaya-gaya komunikasi yang memungkinkan orang-orang tinggal dalam suatu masyarakat di suatu lingkungan geografis tertentu pada suatu tingkat perkembangan teknis tertentu dan pada suatu saat tertentu (Porter dan Samovar, Dalam Mulyana dan Rakhmat 2009 : 18).

Komunikasi antarbudaya diantara mereka tentunya dipengaruhi oleh faktor budaya, sosiobudaya, psikobudaya dan lingkungan. Keempat faktor ini memerlukan proses adaptasi dan penyesuaian diri, yang mana para ahli sering menggunakan istilah akulturasi sebagai bahasa rujukan kepada penyesuaian individu terhadap suatu budaya yang baru. Akulturasi merupakan proses adaptasi yang dilakukan oleh seorang imigran yang dapat membantunya dalam berinteraksi dengan masyarakat pribumi (penduduk asli yang menaungi suatu wilayah). Begitu seorang imigran memasuki budaya pribumi, proses akulturasi mulai berlangsung. Proses akulturasi akan terus berlangsung selama imigran mengadakan kotak langsung dengan sistem sosio-budaya pribumi. Kim mengungkapkan bahwa "Semua kekuatan akulturatif - komunikasi persona dan sosial, lingkungan komunikasi, dan potensi akulturasi sebelum berimigrasi-secara interaktif mempengaruhi jalannya perubahan pada proses akulturasi imigran”. (Kim, dalam Mulyana \& Rakhmat 2009 : 146). 
Dian Fitriana, Pengaruh Akultrasi dalam Proses...

Komunikasi persona yang dimaksudkan disini adalah komunikasi yang terjadi dalam diri setiap individu dalam melihat dan mengamati apa yang terjadi di sekitarnya. Mengenai bagaimana ia memandang, melihat dan memahami segala sesuatu yang nantinya akan diolah dalam diri pribadi tersebut.

Komunikasi sosial yaitu ketika dua atau lebih individu berinteraksi, sengaja atau tidak. Melalui komunikasi sosial individu-individu "menyetel" perasaan perasaan, pemahaman, dan perilaku-perilaku antara yang satu dengan yang lainnya. Dengan kata lain dalam komunikasi sosial ini manusia dituntut untuk mampu mengatur kognisi, afeksi dan perilakunya baik terhadap sesuatu hal. Komunikasi sosial dapat dikategorikan lebih jauh ke dalam komunikasi antarpersona dan komunikasi massa.

Lingkungan komunikasi adalah lingkungan dimana suatu imigran berkomunikasi atau melakukan interaksi sangatlah berpengaruh terhadap perubahan perilaku dalam upaya penyesuaian diri yang dilakukan oleh suatu imigran di tempat perantauan tersebut. Adanya komunitas etnik imigran di wilayah baru akan mempermudah imigran dalam melakukan suatu adaptasi dengan menghambat masalah-masalah mental dan psikologi seorang imigran ketika berada di tempat baru. Seperti yang diungkapkan oleh Kim bahwa:"Suatu kondisi lingkungan yang sangat berpengaruh pada komunikasi dan akulturasi imigran adalah adanya komunitas etniknya di daerah setempat".(Kim dalam Mulyana dan Rakhmat 2009 : 140-144).

Young Yun Kim mengemukakan bahwa :

Dalam Potensi akulturasi, individu-individu merespon perubahan baru dengan berdasarkan pengalaman mereka terdahulu. Mereka akan menerima apa yang menguntungkan dan menolak apa yang merugikan. Pola-pola akulturasi tidaklah seragam dan sama antara individu-individu tetapi beraneka ragam, bergantung pada potensi akulturasi yang dimiliki imigran sebelum berimigrasi. Dari sekian banyak faktor, faktor-faktor berikut dianggap penting dalam memberi andil kepada potensi akulturasi yang besar (Kim, dalam Mulyana \& Rakhmat 2009:144).

Perkembangan jaringan komunikasi dan meningkatnya jumlah orang yang berkunjung dan menetap disuatu negara lain, baik untuk sementara maupun untuk selamanya, telah menumbuhkan kesadaran akan penting dan perlunya memahami 
budaya orang lain. Budaya asing telah menjadi suatu bagian yang penting dalam lingkungan komunikasi mereka. Mereka yang dapat mengatasi masalah-masalah budaya secara efektif inilah, baik dalam konteks nasional (hubungan antarmanusia yang berbeda budaya dalam suatu negara) ataupun dalam konteks internasional (hubungan antara manusia yang berbeda budaya dan negara), dapat disebut manusia-manusia antarbudaya.

Menurut Gudykunst dan Kim, "Manusia antarbudaya adalah Orang yang mencapai tingkat tinggi dalam proses antarbudaya yang Kognisi, Afeksi, dan Perilakunya tidak terbatas, tetapi harus berkembang melewati parameterparameter psikologis suatu budaya" (Kim dalam Mulyana, 2009 :232-233).

Bahasa mempunyai kemampuan dan keampuhan untuk mendekatkan jarak sosial, ekonomi-budaya di antara anggota-anggota masyarakat. Bahasa dapat diartikan sebagai perangkat semua kalimat yang diterima dan yang dapat di konstruksi dari seperangkat kata, bahasa itu sendiri adalah simbol dengan aturan yang mengkombinasikan simbol-simbol tersebut yang digunakan dan dipahami oleh suatu komunitas. Bahasa dapat digolongkan sebagai unsur kebudayaan karena pada hakikatnya bahasa mengikuti inti pengertian defenisi kebudayaan.

\section{Metode dan Sasaran Penelitian}

Metode penelitian yang dipakai adalah Path Analysis, yang bertujuan untuk untuk meneliti sejauh mana variasi pada satu faktor berkaitan dan sekaligus mempengaruhi variasi pada faktor lain. Selanjutnya adalah menentukan berapa besar pengaruh suatu variabel terhadap variabel lain. Untuk menentukan besarnya pengaruh variabel terhadap variabel lainnya baik itu pengaruh langsung maupun pengaruh tidak langsung adalah menggunakan analisis jalur (Path Analysis). (Sitepu, $1994: 1-2$ ).

Dalam hal ini fakta yang dipaparkan adalah pengaruh akulturasi mahasiswa Sulsel di Kota Bandung dari segi Komunikasi Persona, Komunikasi Sosial, Lingkungan Komunikasi, dan Potensi Akulturasi terhadap kesadaran budaya berbahasa. Agar mempermudah pengambilan data, maka populasi dibagi 
menjadi cluster-cluster berdasarkan universitas di Wilayah Utara Kota Bandung yang didalamnya terdapat Organisasi Daerah (ORGANDA) Mahasiswa Sulsel, berjumlah 7 universitas. Teknik pengambilan data dilakukan dengan empat cara, yaitu (1)Angket/Kuisioner, (2)Wawancara terikat, (3)Pengamatan, dan (4) Study Pustaka kepada para Mahasiswa Sulsel di Wilayah Utara Kota Bandung.

\section{PEMBAHASAN}

\section{Akulturasi terhadap Kesadaran Budaya Berbahasa}

Diagram 1: Pengaruh Terhadap Kesadaran Budaya Berbahasa (Secara Simultan)

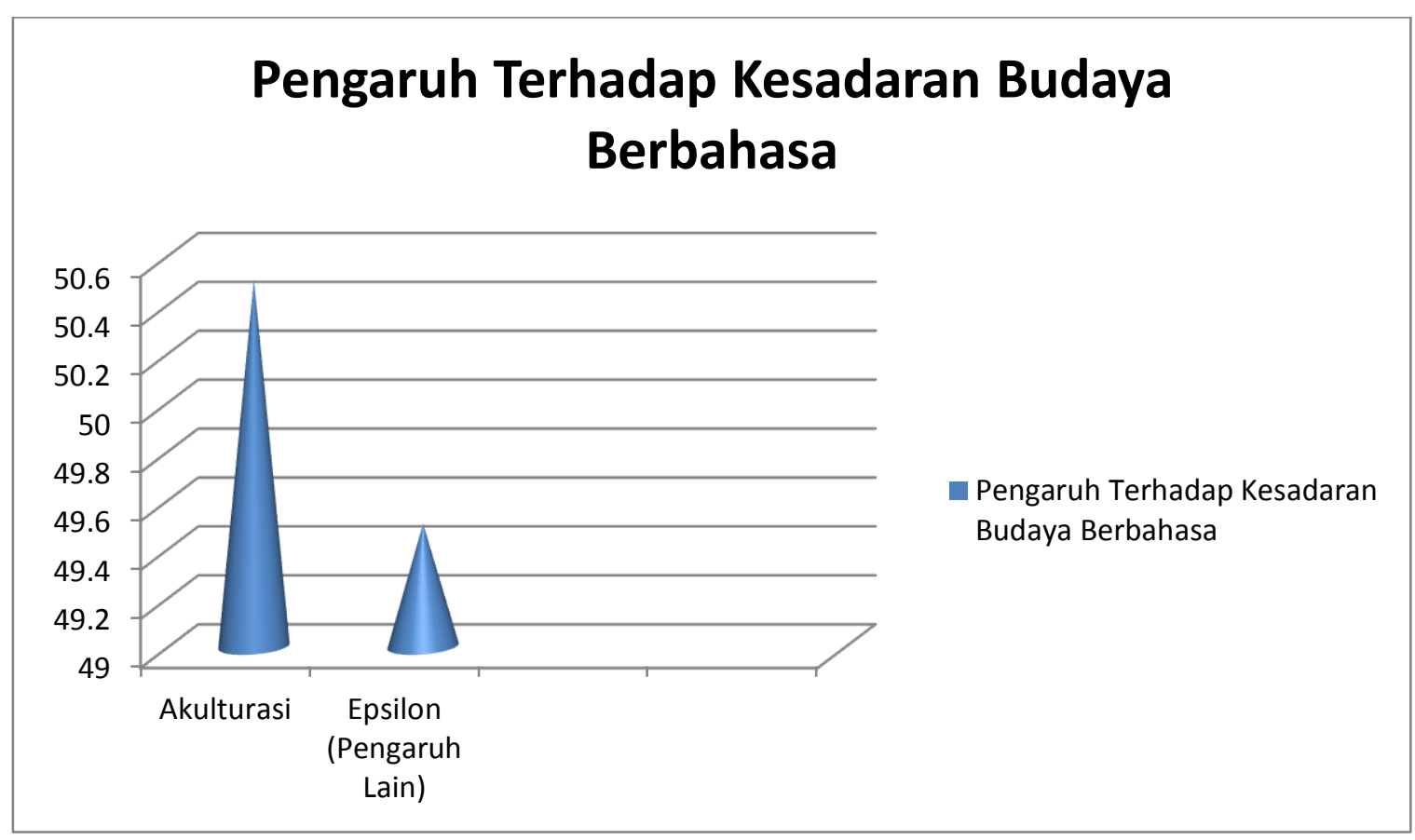

Sebagai anggota baru dalam budaya pribumi, imigran dihadapkan oleh berbagai aspek kehidupan yang asing. Mulai dari tata cara berbicara, berprilaku, sampai pada pola pikir dan cara pandang yang berbeda dengan pribumi. Namun, secara bertahap imigran belajar menciptakan situasi dan relasi dalam hal ini berteman dan bergaul dengan cara yang baik pada masyarakat pribumi sejalan dengan berbagai interaksi yang dilakukan dengan orang lain.

Upaya-upaya yang dilakukan mahasiswa Sulawesi Selatan sebagai bentuk pembelajaran secara bertahap adalah bergaul dengan masyarakat asli Sunda, ikut terlibat dalam kegiatan sosial budaya baik itu dilingkungan kampus maupun di 
lingkungan etnik Sunda, sampai memiliki teman dekat yang berasal dari masyarakat asli Sunda. Seperti yang dikemukakan oleh Adler bahwa "Melalui proses sosialisasi dan pendidikan, pola-pola ditanamkan pikiran dan menjadi bagian kepribadian dan perilaku kita”(Adler, dalam Mulyana dan Rahmat, 2009:138). Hal ini telah sampai kepada titik derajat keintiman dalam berkomunikasi dengan masyarakat pribumi, sehingga dapat mempermudah para mahasiswa pendatang dalam memahami secara jelas mengenai budaya dan bahasa asli Sunda

Masalah-masalah komunikasi lainnya meliputi masalah komunikasi nonvebal maupun verbal antara lain jarak sosial, intonasi suara, penggunaan kosa kata yang berbeda sehingga apa yang dikatakan akan diartikan berbeda oleh masyarakat pribumi. Namun berdasarkan hasil penelitian, masalah-masalah komunikasi tersebut masih bisa diatasi oleh mereka. Meskipun dalam kehidupan sehari-hari sering dijumpai kesulitan dalam memaknai sesuatu namun tidak berdampak negatif yang terlalu jauh.

Proses komunikasi dan interaksi mendasari proses akulturasi seorang imigran. Dimulai dengan mengetahui, memahami, mampu mengidentifikasi sampai pada kemampuan dalam mengklasifikasikan Bahasa Sunda. Seorang imigran akan mengatur dirinya untuk mengetahui dan diketahui dalam berhubungan dengan orang lain, dan hal tersebut dilakukan seorang imigran dengan cara berinteraksi. Dengan menerima bahasa, menghargai dan bersikap empati terhadap bahasa setempat (bahasa Sunda) maka akan menjadi langkah yang akan menunjang seorang imigran dalam berprilaku terhadap bahasa tersebut. Sebagai pendatang, mereka perlu membangun pola kehidupan baru dan menjadi anggota dari masyarakat pribumi. Upaya pembelajaran yang mereka lakukan dengan cara bergaul dengan masyarakat asli, ikut terlibat dalam kegiatan sosial budaya, sampai kepada menjalin kedekatan yang lebih intim dengan masyarakat asli Sunda.

Masalah komunikasi meliputi verbal dan non verbal yang berbeda tersebut masih bisa diatasi dan tidak berdampak negatif yang terlalu jauh. Penyesuaian diri 
yang sebagian besar dari mereka dilakukan telah sampai pada tahap mampu menggunakan bahasa Sunda dan mampu menempatkan konteks berbahasa dengan cukup baik. Sehingga dapat dikatakan bahwa Upaya akulturasi dapat membantu membangun kesadaran akan budaya khususnya dalam hal berbahasa setempat.

Diagram 2 Pengaruh Terhadap Kesadaran Budaya Berbahasa

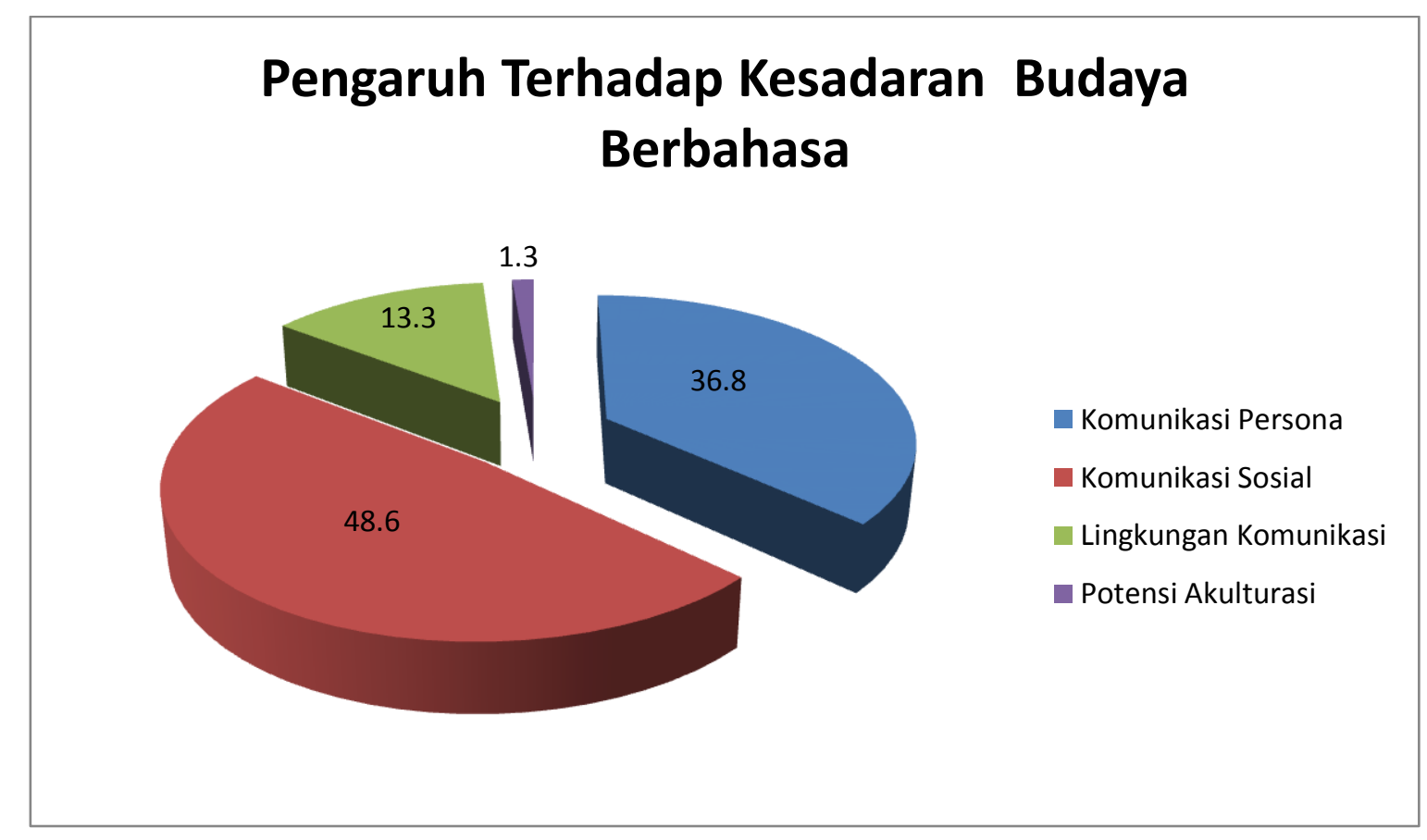

\section{Komunikasi Persona}

Kriteria komunikasi persona berupa pemahaman responden mengenai perbedaan budaya cukup signifikan. Sebagian besar responden memperbanyak interaksi dengan masyarakat Sunda untuk memahami budaya Sunda. Keinginan untuk memahami kebudayaan Sundamembuktikan bahwa penerimaan mereka mengenai bahasa Sunda adalah hal yang positif. Umumnya mereka termasuk kedalam pelaku budaya yang memanfaatkan kebudayaan dengan pola perilaku untuk menyesuaikan diri. Adanya sikap positif dalam memahami kebudayaan Sunda. Adanya keinginan untuk bergaul dengan masyarakat pribumi (Sunda). Mereka memiliki kemampuan untuk mengidentifikasi, mengklasifikasi dan menggunakan bahkan telah sampai kepada memperkenalkan dan mengembangkan bahasa Sunda. 
Dian Fitriana, Pengaruh Akultrasi dalam Proses...

\section{Komunikasi Sosial}

Mereka banyak aktif dan terlibat kegiatan sosial-budaya yang diselenggarakan organisasi kemahasiswaan kampus. Terjalinnya pergaulan dengan masyarakat Sunda dalam hal ini yang berasal dari etnik Sunda (mis: Paguyuban, Sanggar, dll). Memiliki derajat keintiman dalam berkomunikasi yang baik, karena sebagian besar memiliki teman dekat dari Suku Asli Sunda. Interaksi dan membutuhkan komunikasi yang intens menimbulkan kualitas komunikasi yang menciptakan pola hubungan yang lebih dekat. Mereka tidak dengan sengaja mengakses media massa untuk mengetahui karakteristik dan informasi mengenai masyarakat Sunda. Diasumsikan bahwa mereka masih belum seutuhnya memanfaatkan media massa untuk menafsirkan lingkungan.

\section{Lingkungan Komunikasi}

Lingkungan Komunikasi adalah lingkungan tempat tinggal dan lingkungan pergaulan responden yang menunjang kemampuan akulturasi. Sebagian besar responden tinggal di Asrama khusus mahasiswa Sul-sel. Umumnya mahasiswa Sulsel bertempat di tengah permukiman masyarakat Sunda asli. Sebagian dari mereka tidak setuju dengan keterlibatan dalam komunitas etnik Sunda di sekitar tempat tinggalnya. Kondisi kampus juga memberikan efek dominan dalam memberikan transfer budaya. Sebagian besar dari mereka terlibat dalam organisasi dan kegiatan komunitas sulsel khususnya kegiatan yang bersifat interaksi dengan masyarakat Sunda.

\section{Potensi Akulturasi}

Dengan adanya kemiripan-kemiripan budaya antara budaya Sunda dengan budaya yang berada di Sulawesi-Selatan, diharapkan dapat mempermudah dalam beradaptasi dengan budaya setempat. Selain terdapat kemiripan juga terdapat perbedaan yang cukup signifikan. Perbedaan yang paling utama adalah dialek dan kebiasaan sehari-hari. Dalam hal kepribadian, kondisi usia remaja para mahasiswa sangat mempengaruhi sikap ingin tau, senang berpetualang dan percaya diri dalam 
menghadapi kehidupan baru. Mayoritas mereka menyikapi perbedaan pendapat/pola pikir yang biasa terjadi adalah hal yang wajar dan disikapi secara dewasa. Mayoritas mereka sering mendengarkan dan mengetahui bahasa dan kebiasaan masyarakat Sunda sebelum berkunjung ke Kota Bandung. Setelah melihat uraian mengenai potensi akulturasi, baik itu mengenai kemiripan antarbudaya, kepribadian, pengetahuan tentang budaya pribumi sebelum merantau ke tanah Sunda sebenarnya dapat mempertinggi potensi akulturasi mereka, namun berdasarkan hasil penelitian, hal tersebut tidak berdampak jauh terhadap kesadaran budaya berbahasa.

\section{Pengaruh Epsilon (Pengaruh lain)}

- Faktor Eksternal : Diawali dengan faktor kebutuhan mereka. kebutuhan akan sarana penunjang pendidikan mereka sebagai seorang mahasiswa.

- Faktor Internal : Karakteristik dalam diri setiap individu . Misalnya kemampuan berbahasa dan mengadaptasi bahasa dan dialek dengan cepat, kepercayaan diri, dan historis yang membuat mereka memiliki kedekatan emosional dengan masyarakat Sunda.

\section{KESIMPULAN}

Hasil temuan pada penelitian ini adalah terdapat pengaruh yang signifikan pada Akulturasi dalam proses interaksi antarbudaya terhadap kesadaran budaya berbahasa di kalangan mahasiswa Sulawesi Selatan di Kota Bandung. Namun sesuai dengan identifikasi masalah ditemukan bahwa, Indikator dari Akulturasi yaitu Komunikasi Persona dan Komunikasi Sosial memiliki pengaruh yang bersifat signifikan terhadap Kesadaran Budaya Berbahasa dikalangan mahasiswa Sulawesi Selatan di Kota Bandung, yang masing-masing persentasenya sebesar $36,8 \%$ dan 48,6\%. Selain itu hasil penelitian juga menemukan bahwa indikator akulturasi lainnya Lingkungan Komunikasi dan Potensi Akulturasi memiliki pengaruh yang bersifat tidak signifikan terhadap Kesadaran Budaya berbahasa yang masing-masing persentasenya sebesar $13,3 \%$ dan $1,3 \%$. Selain itu juga 
terdapat $49,5 \%$ pengaruh lain (Epsilon) yang mempengaruhi kesadaran budaya berbahasa.

\section{DAFTAR PUSTAKA}

Alwisol. 2009. Psikologi Kepribadian. UMM Press Malang.

Atkinson, Rita L dkk. Pengantar Psikologi. Interaksar. Batam.

Kriyantono, Rachmat. 2006. Teknik Praktis Riset Komunikasi. Kencana Prenada Media Group. Jakarta. Koentjaraningrat, 2002. Manusia dan Kebudayaan di Indonesia. Djambatan. Jakarta.

Prasetyo, Bambang dkk. 2005. Metode Penelitian Kuatitatif. PT. Raja Grafindo Persada. Jakarta.

Rakhmat, Djalaluddin dkk. 2009. Komunikasi Antar Budaya. PT Remaja Rosdakarya. Bandung.

Sihabudin, Ahmad. 2011. Komunikasi Antar Budaya. Bumi Aksara. Jakarta.

Sitepu, Nirwana SK. 1994. Analisis Jalur (Path Analysis). Unit pelayanan Statistika FMIPA UNPAD. Bandung Suparmoko, M. 1999. Metode Penelitian Praktis. BPFE Yogyarakta. Yogyakarta

Supranto. 2007. Teknik Sampling Untuk Survey \& Eksperimen. PT. Rineka Cipta. Jakarta. 